\title{
The Role of Muslim Migrants in the Spread of Islam in East Africa: A Case Study of Uganda
}

Aiseta Aisha

Islamic University in Uganda-Uganda

\begin{abstract}
The spread of Islam in Uganda is attributed to both foreign and local Muslim migrants. These included the Khartoumers who arrived in northern Uganda in 1830, the Arabs who arrived in 1844 and the Baganda, the first local community to receive Islam. The latter was instrumental in the spread of Islam in the Eastern and Western parts of the country. In the East, a group of Muslims arrived in the area with Semei Kakungulu around the twentieth century, a British colonial agent, and in their interactions with the locals they passed on tips of Islam to them. In the West, it was the Muslim refugees of the political and religious wars of 1880s/1890s that played a significant role. Muslims in Uganda still lag behind in many sectors and are divided along tribalistic grounds. However, the Baganda believe that they greatly contributed to the spread of Islam in the country. Thus, they should produce the overall Muslim leadership, a development which the other tribes cannot accept. They argue that although Islam entered Buganda first, it was not the Baganda who brought it. They, however, acknowledge the role played by the above-mentioned migrants. That is said, this paper illustrates how migrants contributed to the spread of Islam in Ugandaanalysis statistical method covering eight distinct retail elements through a nationwide sampling dispersal.
\end{abstract}

Keywords: migrants, Muslims, Islam, refugees, Baganda, Arabs, Khartoumers, Nubians, Berbers

\section{Introduction}

Islam refers to the total submission to the will of Allah, where the followers use Quran and hadith as sources of guidance. The religion is believed to have started way back in the 7th century during the days of Prophet Muhammad SAW, with only a handful of followers. Today it is ranked as one of the most influential religions in the world, with followers spread across the many regions of the world. Among the many factors that aided the spread of the religion is the role played by migrants who traveled either for commerce or asylum. For East Africa and Uganda, in particular, the profitable longdistance trade saw an influx of Muslim migrants into the country, which aided the development of the new religion (Kombo, 2015, p.1). 
According to Farlex (2003), the term "migrants" appears to be a complex term as different scholars give different meanings to the word (p. 2). According to the Cambridge Dictionary (n.d.), the word "migrant" means "one that moves from one region to another by chance, instinct, or plan or as an itinerant worker who travels from one area to another in search of work". When the epithet Muslim migrant is applied to the definition it may refer to the Muslims who moved from their original areas of settlement and, as a result, contributed to the spread of Islam in the areas where they arrived.

A migrant would be categorized into a local migrant or foreign migrant. A foreign or international migration occurs when a person moves from a country of origin to a host nation while, on the other hand, a local migrant may refer to a person who moves from one area to another without leaving the country of origin (Adepoju \& stalkers, 2001, p. 20). Muslim migrants were, in fact, migrants who left their countries of origin for several reasons as I will show below.

There is a dearth of literature that has been written on the entrance of Islam into Africa in general, and its spread in Uganda in particular. One of the available works is The Spread of Islam in Uganda by Abdu. B. Kasozi (1986). He identifies two main routes that contributed to the entrance and spread of Islam in Uganda. The central route was mainly associated with the arrival of Arab traders in the kings' palace. The second route was the northern route where Egyptian ivory traders and later Nubian soldiers under Khedive Ismail came to the area in the 1840s. These settled into the areas, mingled with the locals and passed on Islam to them.

Adding to this debate, works such as "Educational Status of Muslims: A Historical Note" by Ibrahim el Zein Soghayroun (1980) brings in another dimension to the debate. He clearly puts it that one of the main reasons that explains the slow pace at which Islam was spread was the lack of an established missionary organization. This was not the case with Christianity. He further explains that the religion was rather spread by traders who were individually interested in doing so. On the contrary, Thomas Almold (2003) in "The Spread of Islam in the World" emphasizes the fact that it was the African converts that passed on Islam to the fellow African natives who were convinced that Islam is a civilization which would raise their social status.

In his book Pre-colonial Immigrants and Colonial Servant Nubians in Uganda, Hansen Bernt (1991) argues that the history of Muslim migrants in Africa is as old as the 7th century. He notes that the Nubians entered Uganda in the early days from the North of the county. It was these migrants that first informally brought Islam to Africa. In a book chapter "Muslims in Buganda: From the Royal Court to Kampala, Isabella", Soi (2011) identifies 1830 as the period when the Khartoumers started Islamic influence in northern Uganda. The Baganda were a centralized group, though trade was the main reason for the arrival of coastal Arabs, i.e. the Arabs and the Swahili.

In "The Beginnings and Development of Islam and Quranic Schools in East Africa", Stanslaus Kombo (2015) argued that commerce greatly contributed to the spread of Islam in East Africa. In particular, he identified long-distance trade as a contributing factor to the spread of Islam in East Africa. Long-Distance trade was a type of trade in the $19^{\text {th }}$ century at the East African Coast. It involved traders 
from the interior of East Africa and exterior communities, mainly Arabs and Persians. As many of the exterior traders were Muslims, they taught Islam to internal traders through their interactions.

The above perspectives from the different scholars will definitely add value to the arguments advanced in this article as discussed below. However, it should be noted that to a greater extent, different scholars concentrated mainly on the entrance and general spread of Islam in Africa and Uganda in particular. They also highly considered trade and individual interest the major reasons for the spread of Islam. Although this gave the author useful information, little attention was given to the role played by Muslim migrants in the spread of Islam in Uganda, which is the main thrust of the current article. The paper presents an overview of the entrance of Islam in Africa and the subsequent regions. Then much attention is given to Uganda as a case study, pointing out the role played by Muslim migrants in the spread of Islam in Uganda.

\section{2- Discussion}

\subsection{Entrance of Islam to Africa}

Unlike other religions that had organized missionary groups, Islam mainly spread by exemplary behavior of Muslims and partly by individual interest particularly of traders as emphasized by Soghayroun (1980, p. 118) and by Trimingham (1964, p.102). Later, it was those converted to Islam who passed on Islam to the native Africans who saw Islam as a civilization and way of raising their social status (Thomas, 2003, p. 335). The compatibility between Islam and the African Traditional religion on matters such as polygamy attracted some converts. Even though Islam limited the number of wives one was allowed to four, this was acceptable to many Africans rather than Christians who were restricted to one wife (Ray, 1976, p. 184).

Mustafa Mheta (2015), while describing the various ways through which Muslim Migrants contributed to the spread of Islam, he identifies dawah (missions) around the mosques, intermarriages and business as the main reasons. He notes that many mosques were built by Muslim migrants. A case in point is Aldinna Mosque in Uganda. The mosques acted as centres where intermarriages were conducted. Some of the marriages were between a Muslim man and a non-Muslim lady who ended up converting to Islam. The author also notes that many of the migrants came for economic reasons, particularly to carry out trade. Due to the trade links established with the locals, it appealed and attracted non-Muslims to Islam (Mheat, 2015, pp. 1-15). It was these migrants that first informally brought Islam to Africa. The new religion was accepted, and today it has become an integral and influential part of many African cultures and histories. The spread of Islam in Africa was greatly attributed to the role played by Muslim migrants both foreigners and original inhabitants of the country as evidenced below.

\subsection{Islam in West and North Africa and the Role Played by Muslim Migrants}

Margari (2009) states that in West Africa, during the Trans-Saharan trade, North African traders who were Muslims passed on Islam to their West African counterparts whom they came into contact with at the established trade routes (p. 65). This was further proved by Robinson (2004), who noted that during the $11^{\text {th }}$ century, there were reported accounts of Muslim Arab and North African Berber 
settlements in the region (p. 100). It was these that bought Islam to the locals who later spread it in the region. However, in North Africa, the case was quite different, as Islam was introduced as a result of the conquest carried out by the Muslim armies around 639 A.D. during the reign of Umar bin Khattab. This saw the conquest of areas from the Nile to the Atlantic Ocean as pointed out by Spencer (1968, p. 2).

Ray noted that unlike other areas where the spread and introduction of Islam were peaceful (1976, p. 65). However, in areas such as Egypt, there was a lot of bloodshed. Later, with the conversion of many Berbers, they were instrumental in spreading Islam to their neighbors such as Liberia and West Africa through commercial contacts. (Collins ,1983, p. 165). The case was not different from Somalia as noted by Triminghan (1968) that they came into contact with Arab and Persian migrants as early as the 7th century A.D, who had established a series of settlements along the coast where they gradually converted some of the people they came into contact with (p. 2). According to Buira (2002, p. 6), from the 11th to 13th centuries, Somalia witnessed a massive conversion of the natives to Islam with the arrival of Sheikh Ishaaq and Sheikh Darood Jabarti from Arabia, thus, justifying the role that migrations played in Islamization.

\subsection{Islam in East Africa (Kenya and Tanganika) and the Role Played by Muslim Migrants}

Equally, both on the coast and in the interior of East Africa, Muslim migrants played important roles in the spread of Islam. It is imperative to note that Muslim settlements on the coast of East Africa were present as early as the 8th century as evidenced by Archaeological findings in Shanga and Pate Island. Following the development of the Indian Ocean trade after 1100 A.D, Arnold (2003) notes that there was equally an increase in the Muslim settlers from Oman and Iran, etc. (p. 335). In the process of contact with the natives, they passed on Islam to them. However, according to Trimingham (1964), no penetrations were made until the 19th century (pp. 3-20). It is also important to note that, as a result of intermarriages, the foreign traders such as the Arabs and the Bantu, a new group of people, and the Swahili, developed in East Africa (Timothy, 2003, p. 374). Timothy further notes that it was this new group of people that was largely dominated by Muslims that also partly contributed to the spread of Islam in East Africa. However, it is equally important to note that the foreign Muslim migrants who contributed to the spread of Islam in East Africa were mainly from Egypt, Arabia and the Indian Ocean (Lapidus, 1988, p. 429).

As noted earlier, due to increased demand for trade items such as ivory and slaves, the $19^{\text {th }}$ century saw the coastal traders penetrate into the interior of East Africa, taking Islam into the interior where gradually and slowly the religion was passed to the natives in the day to day trade interactions (Vilhanova, 2006, p. 51).

The penetration of Islam into the inlands of East Africa was through two routes. One was the Southern route that connected the coastal towns of Malindi and Kilwa with Lake Malawi region and the trade route that connected Zanzibar with coastal towns of Dar el Salaam with Manyema region and Buganda. Using these connections, Arab and Swahili traders supplied the local chieftains with firearms in exchange for items such as slaves. In the due process of contact, Islam was passed on to some interior leaders who set up small Muslim states, e.g. Tippu Tip and Muteesa I of Buganda. According to Lapidus 
(1988), it was not until the late 19th century that Islam was spread by Individual conversions of those Africans who came into contact with the traders and admired Islam (Lapidus, 1988, p. 435).

Bujra (2002) argues that Tanzania was the main catch point for the spread of Islam in the interior of East Africa (Bujra, 2002, p. 6). This was due to the presence of Zanzibar, which had become a thriving Center of East African trade between the coast and the interior. This encouraged settlements of Swahili and Arabs where they massively converted many people in their day to day life. In Kenya, before colonial rule, Islam had spread to only a few areas such as West and Northeast among the Somalis. This was due to the contacts between caravan traders, who penetrated the area from Tanganyika, and the natives. The building of Uganda railway in 1896 was also a blessing in disguise for the spread of Islam in the interior of Kenya. This was because it made areas like Mombasa important commercial hubs where Muslim traders such as those from Pemba, Zanzibar and migrant laborers from Kikuy and Western Kenya interact. Due to personal admiration of the religion, many of them converted to Islam. When the laborers returned home, they propagated the religion among their people. Many of those that were won over to Islam embraced Islam not as a result of the spiritual message of Allah, but because of being impressed by the Islamic way of life (Nzibo, 2009, p. 1-8).

\subsection{Islam in Uganda and the Role played by Muslim Migrants}

According to Kasozi (1986) in Uganda, Islam entered from two directions, i.e. southern/ Buganda route in the 1840s and the northern Uganda route through the Turko-Egyptian influences in the 1830s. Kasozi, further indicates that the first Muslim Arab trader, Ahmed bin Ibrahim, reached the King's court in Buganda in 1844 (p. 23). On the other hand, Soi (2011) identifies 1830 as the period when the Khartoumers started Islamic influence in northern Uganda (p. 62). The Baganda were a centralized group, though trade was the main reason for the arrival of coastal Arabs, i.e. the Arabs and the Swahili. The Baganda were taught skills of writing in Arabic, using Arabic scripts, and in their continuous contact with them, they managed to have some conversions to Islam thus indicating the role of migrants into the spread of Islam in East Africa (Houstma et al., 1993, p. 992).

In Northern Uganda, West Nile and some parts of Bunyoro, a group of Sudanese Muslim soldiers, who had been employed by Khedive Ismail of Egypt to expand his control over the upper Nile, arrived in 1869 under the leadership of Samuel Baker, a British colonial explorer. Although they met a lot of resistance, they did a commendable job in spreading Islam to the above-mentioned areas as emphasized by Samuel (2003, p. 60) and Twaddle (1993, p. 24.). This was done by, first, converting the recruited able-bodied people such as those from Aringa County, who included men like Addu Anule of Ambala clan, Okuni Diba, Azabo Uruta from Aliapi, and Geriga Ondoga to mention but a few. These men later took the religion to their tribes' men.

Mpoza, A. (2012), however, argues that before the 1830s, some Egyptian, Sudanese, and Turkish traders had penetrated northern Uganda hunting for slaves as early as the 17th century. They established trade routes and introduced Islam informally wherever they passed. Later, the Nubian soldiers strengthened the Islamic influence in Acholi through intermarriages. The Nubians had originally lived in Southern Sudan but, together with Amir Pasha's troops, had been brought into Northern Uganda as 
mercenaries to end the booming slave trade in Northern Uganda. Hansen (1991) further argues that, since the Nubians did not only use Islam as a core value and as identity that formed their basic ways of life, it was what partly helped in the spread of Islam to the people they usually interacted with (pp. 559$560)$.

With the construction of the Uganda railway that started in 1896, and its extension to Eastern Uganda later, a number of Indians were recruited as laborers. Some of them were Muslims and just like the case was for other groups of migrants, the Indians in their interactions with the locals also passed on Islam to them as noted by Mangat (1969, pp. 38-39).

Semakula (1971) notes that the Baganda are also an example of the Muslim migrants who helped in the spread of Islam in Uganda (p.169). It should be noted that Islam entered first in Buganda in 1844 when an Arab trader arrived at King Sunna 11's palace. Kasozi, (1981) further emphasized that Sunna did not convert to Islam, but he welcomed the religion and granted his pages' freedom to convert to it. The pages later who had converted to Islam, took the religion to the people outside the palace (pp. 127135). This, therefore, shows how relevant the Muslim migrants were in the spread of Islam in Uganda. It is also imperative to note that the status of Islam highly depended on the mercy of the king. When Muteesa 1 claimed the political limelight, Islam reached its golden era. Although he did not convert, he declared Islam a state religion, ensuring the observance of acts like prayer and fasting.

When Mwanga came to power, the trend was different as he preferred to denounce all foreign religions. This led to the formation of an alliance of the Muslims and the other religious groups in a bid to overthrow the King. Eventually, the King was overthrown and replaced by Kabaka Kiwewa and Kalema who both were Muslims. This caused more tension by other religious groups in the 1890s. From 1890, the Muslims with their Kabaka Kalema were attacked by the Christians and were forced to go into exile to areas like Ankole, Bunyoro and Busoga. The Baganda Muslims included people like Sheikh Salim Mpulunguse, Ali Kimunyene, Salim Kigulu, Budalaa Mawanda, Adam Mutaasa, Kawuzi, Buddala Kuwala, Ali Tebajanga, Zaid Mukasa Luzundula, Asuman, Abdallah Lubwama, and Kawuzi, who all flocked to Ankole region to seek refuge. In their new homes, however, the exiled Muslims were able to propagate Islam. Thus, exiling these Muslims was always lamented, but there were some positive results from the episode as further expounded by Semakula (1971, pp. 200-218). There is evidence to suggest that during their day to day interactions with the people they came into contact with, they passed on Islam to them especially those that regarded Islam as a civilization and way of raising their social status.

The other group of Baganda Muslim migrants who contributed to the spread of Islam did so along political lines. This category of Muslims had two groups: those that accompanied Semei Kakungulu to Eastern Uganda and those that had been sent by Muslim leaders as teachers of Islam. Semi Kakungulu, was a British colonial agent who was sent to establish a colonial rule to Eastern Uganda. On this mission, he left Buganda with other people among them were some Muslims. Although their aim was not spreading the Islamic religion, the Muslim Baganda administrative followers, in the course of their interaction with the natives, inspired some of them to be converted to Islam. According to Twaddle 
(1993), some of the examples of the Baganda Muslim chiefs that converted to Islam were Bumbakali Kamya, Sale Lule, Jafali Mayanya, and Abudala Makubi (p. 103).

Kitimbo (2009) adds that another group of Baganda Muslim migrants were teachers who were sent by Muslim leaders to other regions in a bid to spread and teach Islam (p. 3). In eastern Uganda, for example, two groups of Muslim teachers arrived from Buganda. Ali Lwanga group (1893-1897) went to Busoga together with Yusuf Kitungul, whereas Yusuf Luzilu, Adam Bwile, Salim Bugweri, KasanKiguru, and Watangalila went to Bugiri. In 1915 the second group was led by Ibrahim, Waiswa Kinyiri. The second group also had Muslims like Twala Sheikh and Ziribamuzale Zacharia. This therefore shows that the Baganda played an important role in the spread of Islam in Uganda. Thus, they held themselves in high esteem in matters of Islam as they always wanted the Muslim leader to be a Muganda. All in all, the Baganda, together with other Muslim migrants, played important roles in the spread and expansion of Islam in Uganda as discussed above.

In Western Uganda, Islam was spread by Muslim migrant refugees. In the years 1888-1891, religious political wars took place in Buganda. It should be noted that since the Christians were superior to their Muslim counterparts not only in numbers but militarily as well, the latter were defeated. As a result, they opted to seek refuge in different parts of Uganda; a big number of the defeated Muslims went to the West where they particularly settled in areas like Ankole region. These Muslim migrants, thus once again, promoted the spread of Islam. Though accidentally in their free time, they passed on tips of the religion to the people they interacted with as has been noted by Semakula (1971, pp. 200218).

Another foreign migrant Muslim group that was influential in the spread of Islam in Uganda was the Asians. These came to Uganda mainly for two reasons: first as colonial laborers to aid in the infrastructural development and secondly some of them came mainly for economic reasons as traders. It is important to note that the majority of these groups were mainly Muslims from the Ismailia Muslim sect as noted by Soi (2016, pp. 171-172). These contributed to the spread of Islam in education from as early as the 1940s when they established Muslim-founded Schools that saw a number of Muslims children attaining education.

\section{Conclusion}

This article intended to establish the role played by Muslim migrants in the spread of Islam in Uganda. An attempt was made to, first, explain how Islam arrived in Africa and the roles that different migrants played in spreading the religion. It highlights the tremendous role played by the Arab merchants, the Berbers, the Sudanese Nubians (Khartoumers), Persians and Asians in the spread of Islam in Africa. The paper further acknowledged that unlike Christianity that had an organized mission to spread the religion, Islam was mainly spread peacefully by both foreign and local Muslim migrates in Uganda. Many of the foreign migrants came for economic reasons but ended up indirectly spreading Islam, since a Muslim is inseparable from his religion. On the other hand, the local Muslim migrants, particularly in Uganda, were either those that had accepted Islam and had influential political positions which they used to spread the religion like those that accompanied Kakungulu to the East, or the 
defeated Muslim migrants who went as refugees to the western parts of the country. The paper also acknowledges that, as the migrants played a significant role in the spread of Islam in Uganda, there were other silent factors such as compatibility between Islam and the African traditional religion that, in one way or the other, played a role in enhancing the spread of the religion in Uganda.

\section{References}

[1] Adepoju, A. (1991). South- North migration: The African experience. International Migration, 29(2), 207-221. https://doi.org/10.1111/j.1468-2435.1991.tb01015.x

[2] Bujra, A. (2002), Islam in east Africa: Historical legacy and contemporary challenges. PDF4PRO. Retrieved July 18, 2020 from https://pdf4pro.com/view/islam-in-eastern-africa-historical-legacyand-46f971.html

[3] Cambridge University Press. (n.d.) Migration. In Cambridge dictionary. Retrieved July 2, 2020, from dictionary.Cambridge.Org/dictionary/migrant

[4] Farlex, (2003). Migrant. In The free dictionary. Retrieved July 3, 2020, from www. The free dictionary.com/migrant Googlesearch

[5] Hansen, H. B. (1991). Pre-colonial immigrants and colonial servant. The Nubians In Uganda Revisited. African Affairs, 90(361), 559-580. http://www.jstor.org/stable/722844

[6] Houtsma M. T., Wensinch A. J., Arnold T. W., Heffening W. \& E. Lévi-Provençal (Eds.). (1993). E. J. Brill's First encyclopedia of Islam 1913-1936. (Vol. IV, pp. 583-1168). Library of Congress Cataloging Publication Data.

[7] Kasozi, A. B. (1981). Impact of Islam on Ganda culture, 1844-1894. Journal of Religion in Africa, 12(2)127-135. http;//www.jstor.org/stable/1580857

[8] Kasozi, A. B. (1986). The Spread of Islam in Uganda. Oxford University Press.

[9] Kasumba, Y. (1995). The development of Islam in Uganda 1962-1992, with Particular reference to Religio-Political Factionalism. (Unpublished M.A. thesis). Makerere University.

[10] Kombo, S. (2015). The beginnings and development of Islam and Quranic schools in East Africa. Journal of Philosophy, Culture and Religion, 6. 1-7. http://www.iiste.org/Journals/index.php/JPCR/article/view/20843/21103

[11] Kitimbo, A. (2009, April 20 ${ }^{\text {th }}$ ). Ensasanya yo obusiramu mu Uganda [The spread of Islam in Uganda] [Paper presentation]. At Muslim Leaders Workshop, Kibuli.

[12] Lapidus, I. (1988). History of islamic societies ( ${ }^{\text {rd }}$ ed.). Cambridge University Press.

[13] Mangat, J. S. (1969). A history of the Asians in east Africa, ca. 1886 to 1945. Clarendon Press.

[14] Margari H. (2009). The spread of Islam in west Africa: Containment, mixing, and reform from the Eighth to the twentieth century. Stanford. Retrieved from 
https://spice.fsi.stanford.edu/docs/the_spread_of_islam_in_west_africa_containment_mixing_an d_reform_from_the eighth_to_the twentieth_century

[15] Mheta, M. B. (2015). The role Muslim Migration plays in the islamization of Sub-Saharan Africa: A focus on the post modern era. Academia.edu.

https://www.academia.edu/8901277/THE_ROLE_MUSLIM_MIGRATION_PLAYS_IN_THE_I SLAMIZATION_OF_SUB_SAHARAN_AFRICA_A_FOCUS_ON_THE_POST_MODERN_E $\underline{\mathrm{RA}}$

[16] Mpoza, A. (2012, February 1). It has been 170 years of Islam in Uganda. Daily Monitor. Retrieved on 15/july 2020 from https://www.facebook.com/128372957263072/posts/the-170-years-ofislam-in-uganda-by-abdulhamid-mpozawhoever-ignores-history-phil/463708123729552/

[17] Vilhanova, V. (2006). Similarities and differences in the spread of Islam: East and South Africa compared [Paper presentation]. Islamic Civilization in South Africa, Johannesburg, South Africa.

[18] Ray, B. C. (1976). African Religions: Symbol, ritual and community ( $2^{\text {nd }}$ edition). Englewood cliffs.

[19] Robinson, D. (2004). Muslim societies in African history (New Approaches to African History). Cambridge University Press.

[20] Semakula, K. A. (1971). History of Buganda from the Foundation of the kingdom to 1900. Longman.

[21] Soghayroun, I. (1980). Educational status of Muslims: A historical note. Institute of Muslim Minority Affairs Journal, 2(1). https://www.tandfonline.com/doi/abs/10.1080/02666958008715798 (Published on line on $20^{\text {th }}$ March 2007)

[22] Soi, I. (2016). The Muslim minority in Uganda. The historical quest for unity and inclusion. Africana, XXII, 167-180. Retrieved from research gate.net/publication/312278155/the-muslismminority-in -uganda.historical-quest for unity and inclusion

[23] Soi, I. (2011). Muslims in Buganda from the royal court to Kampala. In I. Soi \& F. Petrucci, (Eds.), Cities and minorities in Africa (pp.61- 68). https://www.researchgate.net/publication/282571669_soi__muslims

[24] Samuel , B. S. (2003). Ismailia. Retrieved $13^{\text {th }}$ July 2020, from www.gutenberg.org/ebook/3607

[25] Thomas, A. (2003). The spread of Islam in the world: A history of peaceful preaching. Goal Word Books.

[26] Timothy, I. (2003). The Archaeology of Islam in Sub-Saharan Africa. Cambridge University Press.

[27] Triminghan, S. (1968). The influence of Islam upon Africa, Longmans. 
[28] Twaddle, M. (1993). Kakungulu and the creation of Uganda, 1886-1928. Ohio University Press. 